\title{
Undervisning i kirkekunnskap - religionspedagogiske refleksjoner
}

Av Ola TృøRном, professor emeritus, Universitetet i Agder. E-post: ola.tjorhom@uia.no

En ny lærebok i konfesjonskunnskap foreligger, denne gang presentert som kirkekunnskap. ${ }^{1}$ I løpet av skriveprosessen ble vi som forfattere stilt overfor flere religionspedagogiske og didaktiske utfordringer. Dette bidraget er ikke tenkt som en slags «selvanmeldelse» av boken, andre får vurdere det ferdige produktet. Men jeg vil dele noen refleksjoner omkring et fagfelt i endring, som kan være nyttige med sikte på religionsfaget i vid forstand.

Konfesjonskunnskap har lenge stått sentralt innenfor norsk teologi og vår religionsundervisning på alle plan. Einar Mollands verk Kristenhetens kirker og trossamfunn (første utgave i 1953) er en klassiker, også internasjonalt. Blant seinere bidrag nevnes Carl Fredrik Wisløff: Kristne kirkesamfunn (1974), Peder Borgen og Brynjar Haralds $\emptyset$ (red.): Kristne kirker og trossamfunn (1993), samt Helje Kringlebotn Sødal (red.): Det kristne Norge. Innføring i konfesjonskunnskap (2001). Kun Borgen og Haralds $\emptyset$ s bok anvender et innenfra-perspektiv hvor medlemmer av de forskjellige kirketradisjonene selv står for framstillingen.

Når kirkelivet betraktes utenfra, kan det virke statisk og lite åpent for fornyelse. Samtidig finnes det interne røster som klager over manglende stabilitet. Sannheten er nok at så godt som alle kirkesamfunn har gjennomgått store forandringer, særlig siden 1950-tallet. Dette gjelder også tradisjoner som betrakter kontinuitet som et viktig anliggende. Noen endringer har kirkene selv initiert, andre har sin bakgrunn i eksterne forhold.

Et kirkelandskap i forandring er hovedårsaken til at nye innføringer i konfesjonskunnskap publiseres med jevne mellomrom. Men bøkene har i mindre grad medvirket til fornyelse av fagfeltet som helhet. I den nylig utgitte boken inngår følgende punkter $\mathrm{i}$ et fors $\emptyset \mathrm{k}$ på å oppdatere konfesjonskunnskapen og utvide dens rammer.

\section{KIRKEKUNNSKAP I STEDET FOR KONFESJONSKUNNSKAP}

Konfesjonskunnskapsfaget ble i dets tidlige faser ofte omtalt som symbolikk, knyttet til en drøfting av kirkenes symboler eller bekjennelser. ${ }^{2}$ Konfesjon betyr i utgangspunktet bekjennelse, men brukes også som betegnelse på de forskjellige

1 Se Ola Tjørhom (red.), Kirkesamfunn i Norge. Innføring i kirkekunnskap, Oslo: Cappelen, 2018.

2 Jf. bla. den klassiske framstillingen Johann Adam Möhler, Symbolik oder Darstellung der dogmatischen Gegensätze der Katholiken und Protestanten nach ihren öffentlichen Bekenntnisschriften, første utgave 1832. 
kirketradisjonene eller kirkefamiliene. Noen bekjennelser er konfesjonsspesifikke, andre har brei $\emptyset$ kumenisk oppslutning. Selv om konfesjonskunnskapen i $\emptyset$ kende grad vektla flere sider ved det kirkelige livet, har fokuset på bekjennelsesaspektet tradisjonelt vært sterkt. Dette ga rom for normative perspektiver, kombinert med komparative innfallsvinkler.

Lære- og bekjennelsesbaserte identiteter står fortsatt sentralt innenfor de fleste kirkesamfunn, om enn på ulike premisser. Slike identiteter forankres gjerne i formulerte bekjennelser, kortere til bruk i gudstjenesten og lengre for å ivareta lære. Dette reflekterer kirkenes karakter som trossamfunn, instanser med forankring i en felles tro. En dekkende framstilling av de kirkelige tradisjonene må derfor innbefatte bekjennelsesgrunnlaget.

Men det konfesjonelle fanger ikke opp bredden og mangfoldet i kirkenes liv. En rekke andre faktorer spiller med når kirkelige identiteter får sin form, og dette gjelder i $\emptyset$ kende grad. Den nye lærebokens forfattere ble bedt om å redegjøre for blant annet gudstjenesteliv og liturgi, materielle og estetiske trosuttrykk, forholdet mellom kvinner og menn, sosialetisk engasjement og økumenisk praksis - sammen med hovedtrekk i troslæren, kirkenes historie nasjonalt og globalt, samt deres nåværende situasjon og utfordringer.

Kirkelig identitet utformes dessuten ikke i et vakuum, men preges av det som skjer på religionsfeltet totalt sett og i samfunnsutviklingen overhodet. Her har følgende trender betydning: Fra enhetssamfunn til religiøst mangfold, fra konfesjonell identitet til økende økumenisk åpenhet, fra vestlig hegemoni til globalisering, samt følgene av «privatisering» på religionsfeltet hvor folk konstruerer sin egen tro basert på impulser fra forskjellig hold. Slike utviklingslinjer har avgjørende innvirkning på kirkevirkeligheten.

Andre fagfelt medvirker til at disse faktorene blir fanget opp. I denne forbindelse har religionssosiologien spesielt stor betydning. Men en kort innføring i kirkebegrepet, såkalt ekklesiologi, samt et blikk på aktuelle økumeniske utfordringer, bidrar også til en fruktbar utvidelse av faget. Økumenikken fungerer som en betimelig påminning om at ethvert kirkesamfunn arter seg som en del av Jesu Kristi ene kirke.

Alle disse momentene inngår i begrepet kirkekunnskap. Det blir derfor en mer sakssvarende betegnelse på fagfeltet. Kirkekunnskapen står på konfesjonskunnskapens skuldre. Men den nye betegnelsen avspeiler og sikrer en breiere tilnærming. Dette vil gjøre faget mer interessant for elever og studenter på alle plan.

HVILKE TROS- OG KIRKESAMFUNN SKAL OMTALES?

Særlig siden 1970-årene har antallet kirkedannelser nærmest eksplodert, framfor alt i USA. Noen steder medførte dette tilløp til kirkelig atomisering. Under et opphold i Chicago på 90-tallet, registrerte jeg 4-5 nye kirker i samme kvartal 
som knapt kjente til hverandre. De fleste nydannelsene hadde lokal forankring, ofte knyttet til sterke lederskikkelser.

Denne bølgen nådde også Norge, om enn på et mer beskjedent nivå. I vår kontekst har oppsplittingen i stor grad fătt nedslag blant lutheranere. Andre lutherske kirkesamfunn har lenge eksistert utenfor den dominerende statskirken. I det siste har grupperinger som tar avstand fra utviklingen innenfor Den norske kirke, etablert seg som egne samfunn. Og flere lutherske organisasjoner har opprettet selvstendige menigheter.

I denne situasjonen kan kirkekunnskapen aldri bli heldekkende. Kirke- og trostradisjoner med sterk stilling - historisk så vel som aktuelt - må prioriteres, uten å kun ta hensyn til tallmessig oppslutning. Kvekersamfunnet har i dag få medlemmer, men har spilt en viktig rolle i norsk kirke- og samfunnshistorie - ikke minst når det gjelder kampen for religionsfrihet. Ellers kan det være en løsning å fokusere på overgripende kirketyper som behandles i samlekapitler. Og hvis en velger et nasjonalt fokus, kan kirker som er store internasjonalt, men små eller ikke-eksisterende her til lands, framstilles på liknende vis.

Kirkekunnskapen må ellers fange opp nye sentrale trekk i kirkebildet. På hjemlig plan har vi de siste tiårene fătt en rekke migrantmenigheter - noen av disse har tilknytning til eksisterende konfesjoner, andre representerer nye kirkedannelser. Dette er et spennende og berikende innslag i kirkelivet som må presenteres på behørig vis.

Selv om deler av den norske frikirketradisjonen har slitt med synkende oppslutning, fortjener den spesiell oppmerksomhet. Hans Nielsen Hauge og haugianismen førte til at 1800- og 1900-tallets vekkelser i stor grad forble innenfor statskirken. Den protestantiske frikirkeligheten fikk derfor mindre gjennomslag her til lands enn i Sverige. Frikirkene har likevel hatt stor betydning for den norske samfunnsutviklingen. Det gjelder blant annet innføringen av religionsfrihet, sosialt engasjement, bedre kontakt med arbeiderklassen og rom for en emosjonell trostolkning som skilte seg fra den «offisielle» religionen. Kirkekunnskapen har et ansvar for å få fram frikirkenes viktige bidrag.

Det komplekse spørsmålet om hvilke trossamfunn som befinner seg «innenfor» og «utenfor» den kristne kirke, har også relevans for kirkekunnskapen. Sistnevnte omtales noen ganger som samfunn «i randen av» kristenheten. Dette beror ikke bare på at de avvises av andre, det kan være en selvvalgt posisjon. Et utgangspunkt for å konkretisere denne grenseoppgangen finnes i Kirkenes Verdensråds basisparagraf, som et stykke på vei kan leses som en kirkedefinisjon. Her framheves troen på Kristus som frelser, treenighetslæren og Bibelen som fundamentale kjennetegn på kirkelig eksistens. ${ }^{3}$

3 KVs basisparagraflyder slik: The World Council of Churches is a fellowship of churches which confess the Lord Jesus Christ as God and Saviour according to the scriptures, and therefore seek to fulfil together their common calling to the glory of the one God, Father, Son and Holy Spirit (vedtatt på generalforsamlingen i New Delhi 1961). 
INNENFRA - PERSPEKTIV KOMBINERT MED KRITISK REFLEKSJON

For alle kirker er det nyttig å bli vurdert utenfra, av personer som hører hjemme i en annen tradisjon. Knapt noe gir så verdifull innsikt som velfundert ekstern kritikk. Utenfra-perspektivet har vært en hovedlinje i norsk konfesjonskunnskap. Men når kirkesamfunn beskrives av andre, vil anklager om mangler gjerne dukke opp. Slike innvendinger har blitt rettet mot de aller fleste hjemlige innføringer i konfesjonskunnskap.

Når et innenfra-perspektiv velges, står aktive medlemmer i de involverte kirkene for omtalen. Dette gir framstillingen et autentisk, nært og innforlivet preg. Særlig når en tar sikte på en bredt tilgjengelig presentasjon som også fungerer for personer med begrenset erfaring fra kirkelig liv, vil beskrivelser innenfra ofte være mest tjenlige.

Samtidig krever dette perspektivet kritisk bevissthet, blott og bar egenreklame har liten interesse. Behovet for konstruktiv religionskritikk er åpenbart, også i en på mange måter religionskritisk tid. Innenfra-perspektivet må derfor alltid innbefatte selvkritisk refleksjon. Dette kan blant annet sikres ved hjelp av en mal som lister opp spørsmål som skal drøftes. En slik mal kan avdekke at sentrale anliggender er svakt ivaretatt.

\section{EMPIRISK FOKUS PÅ FAKTISK KIRKELIG LIV}

I den nye kirkekunnskapsboken handler det om konkret kirkelig liv innenfor rammen av en mest mulig empirisk tilnærming. Her er poenget ikke hvordan kirker bør være, men hvordan de faktisk er. Selv om drøfting av kirkebegrepet og økumeniske utfordringer vil ha normative innslag, må også disse temaene framstilles så allment og balansert som mulig. Eldre bidrag innenfor konfesjonskunnskapen har i mange tilfeller et sterkere normativt preg, særlig når kun én forfatter er involvert. Dette gjelder i enda større grad ekklesiologien, som ofte får selvbekreftende implikasjoner. Empirisk kirkekunnskap supplerer den tradisjonelle konfesjonskunnskapen på fruktbart vis og korrigerer konfesjonalistisk kirketenkning.

Hensikten med det empiriske fokuset er ikke bare å gi en mest mulig objektiv framstilling, men også å skygge unna det altfor «trostunge». I norsk skole har vi for lengst sagt farvel til konfesjonsbestemt undervisning. Når det undervises i kristen tro på grunnlag av lærebøker som kan leses som en slags «minidogmatikk», vil en imidlertid lett ende opp i nærheten av konfesjonelle posisjoner - tilsiktet eller utilsiktet. En undervisning som vektlegger faktisk kirkelig liv innenfor et bredt spekter av kirke- og trossamfunn, utgjør et konstruktivt alternativ i denne forbindelse. Her definerer det konfesjonelle aspektet ikke hvordan en «sann» kirke ser ut, det skal tvert imot avspeile kristentroens mangfold. 
Dette er etter mitt syn den viktigste didaktiske lærdommen fra kirkekunnskapen. Gjennom fagets empiriske sikte framstår det som et godt alternativ til normative innfallsvinkler i all kristendomsundervisning. Kjennskap til hvordan kirkelig liv arter seg innenfor forskjellige tradisjoner, gir også brei innsikt i kristen tro. Samtidig klargjøres det at troen ikke er uniform og entydig, men mangfoldig og rik. Dette bidrar til gjensidig respekt og toleranse - ikke bare på religionsfeltet, men som allmenne samfunnsmessige verdier.

\section{MøTer MED LEVENDE RELIGION OG TVERRFAGLighet}

Ekskursjoner, bes $\emptyset \mathrm{k}$ i klasserommet og møter med folk fra forskjellige trossamfunn utdyper både innenfra-perspektivet og den empiriske vinklingen. Slike tiltak gir innblikk i hva kristne faktisk tror og hvordan de praktiserer troen sin. Religion er en levende, organisk størrelse som knapt kan studeres på utelukkende teoretisk basis. Men til forskjell fra deltakelse i gudstjenester, vil de møtene med levende religion som finner sted innenfor kirkekunnskapens rammer ha et dokumenterende sikte og inkludere kritiske vurderinger. Dette gjør religionsundervisningen mer autentisk, samtidig som all forkynnelse utelukkes.

Materielle og estetiske trosuttrykk er en viktig innfallsvinkel til det empiriske studiet av religion. Også slike faktorer kan observeres i tilknytning til ekskursjoner og bes $\emptyset \mathrm{k}$ i kirke- og forsamlingsbygg. Forskjeller så vel som likhetstrekk mellom objektene fascinerer, på alle alderstrinn. Noen materielle trosuttrykk har appell utenfor kirkenes sfære.

Til forskjell fra en strikt teologisk konfesjonskunnskap, forutsetter kirkekunnskapen tverrfaglige perspektiver. Her er tilknytningen til allmenn estetikk et godt utgangspunkt. Fag som musikk, kunst og estetikk er spesielt relevante i denne sammenheng.

\section{FRUKTBAR OPPDATERING}

Kirkekunnskapsfaget innebærer etter min oppfatning en betimelig utvidelse av konfesjonskunnskapen, basert på den utviklingen som har skjedd - og fortsatt vil skje - innenfor religionsfeltet. Det empiriske siktet balanserer eller korrigerer normative innfallsvinkler, uten å medføre redusert kunnskap om kristen tro. Faget gir dessuten stort rom for kirkelig mangfold. Denne fagutviklingen representerer en i hvert fall potensielt fruktbar oppdatering av et sentralt innslag $i$ religionsundervisningen. 